\title{
Xylanolytic enzymes production by Aspergillus niger GS1 from solid- state fermentation on corn stover and their effect on ruminal digestibility
}

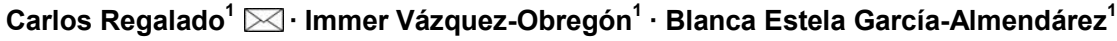 \\ Jorge Domínguez-Domínguez ${ }^{2} \cdot$ Araceli Aguilera-Barreyro $^{3} \cdot$ Aldo Amaro-Reyes $^{1}$ \\ 1 DIPA, PROPAC, Facultad de Química, Universidad Autónoma de Querétaro, México \\ 2 Centro de Investigación en Matemáticas, A.C., Guanajuato, México \\ 3 Laboratorio de Nutrición Animal, Facultad de Ciencias Naturales, Universidad Autónoma de Querétaro, México
}

$\triangle$ Corresponding author: carlosr@uaq.mx

Received March 25, 2010 / Accepted December 21, 2010

Published online: March 15, 2011

(C) 2011 by Pontificia Universidad Católica de Valparaíso, Chile

\begin{abstract}
Hemicellulosic agricultural by-products such as corn stover (CS) are highly available materials which represent an opportunity to develop value added products. Native Aspergillus niger GS1 was used for solid-state fermentation (SSF) on alkali pre-treated CS (ACS) aimed to optimize xylanolytic enzymes production, and their effect on in vitro ruminal and true digestibility of ACS. Enzyme production was empirically modelled using a fractional factorial design $2^{9-5}$, and the resulting significant factors were glucose, yeast extract and two mineral salts, which were arranged in a DraperLin optimization design at two levels. Predicted optimum xylanolytic activity of $33.6 \mathrm{U}(\mathrm{mg} \text { protein })^{-1}$ was achieved at $48 \mathrm{hrs}$ of SSF, and was validated by confirmatory experiments. ACS was incubated with a semipurified enzymatic extract (EE) showing a xylanolytic activity of $1600 \mathrm{U} \mathrm{kg}^{-1}$ dry ACS for $12 \mathrm{hrs}$ before exposure to cow's ruminal liquid for $72 \mathrm{hrs}$, which led to $5 \%$ and $10 \%$ increase of in vitro ruminal and true digestibility, respectively. CS is a readily available by-product in different regions which after alkaline treatment and partial hydrolysis with the EE, may be advantageously used as supplement for ruminant feed.
\end{abstract}

Keywords: Aspergillus niger GS1, corn stover, digestibility, solid-state fermentation, xylanolytic activity

\section{INTRODUCTION}

Corn stover (CS) is an agroindustrial by-product of wide availability in the developing American countries, which is produced at about 23 million tonnes/year in México (Agrifood and Fishery Information Service, 2010) and represents environmental concern since most is disposed of by burning. This fibrous material contains $15-35 \%$ hemicelluloses, and thus may be used for supplementing ruminant feed (Giger-Reverdin, 2000). The cell wall components of forages represent a major energy source for cattle, even though less than $500 \mathrm{~g} \mathrm{~kg}^{-1}$ of this fraction is readily digested and utilized (Eun et al. 2007). Endo- $\beta-1,4$-xylanase (EC 3.2.1.8) and $\beta$-1,4-xylan xylosidase (EC 3.2.1.37) are key enzymes that hydrolyze xylan, the major structural component of hardwood and softwood cell walls, into xylooligosaccharides (Collins et al. 2005).

Xylanase extracts may be incorporated as ruminant feed additives, to improve ruminal fiber digestion resulting in increased digestible energy intake (Pinos-Rodríguez et al. 2002; Giraldo et al. 2008). Furthermore, the demand for xylo-oligosaccharides has increased due to their prebiotic function (Maalej-Achouri et al. 2009). Although there are a limited number of commercially available enzymatic ruminant feed additives, the number of such products is expected to grow (Krishna, 2005).

One method that can be used to produce xylanolytic enzymes is solid-state fermentation (SSF) which is defined as a fermentation process occurring in absence (or near absence) of free water, with enough 
moisture content to support growth and metabolism of microorganisms (Pandey, 2003). SSF is an attractive method for xylanase production, and a large number of different Aspergillus species have been reported as good xylanases producers (Beg et al. 2001; Betini et al. 2009). SSF presents many advantages, such as higher productivity per reactor volume, lower operation and capital costs (Kavya and Padmavathi, 2009), and particularly the possibility of using cost-effective solid agricultural and agroindustrial residues as carbon and energy source for microbial growth (Graminha et al. 2008).

A strain of $A$. niger was isolated from Mexican's copra paste and has proved to produce a variety of cell wall degrading enzymes using different substrates upon SSF (Regalado et al. 2000). Factorial design of experiments is widely used to identify those variables which have a significant effect on the desired response. Once the number of independent variables showing a significant effect is narrowed, response surface methodology (RSM) can be used to optimize fermentation conditions (Liu et al. 2008). This approach keeps the number of experiments to a minimum for relatively large number of factors as compared to those involving the simple, time consuming "one factor at a time" design (Montgomery, 1991).

This work was aimed to optimize xylanolytic enzymes production by $A$. niger GS1 using SSF of supplemented corn stover (CS), and their effect on in vitro ruminal and true digestibility of alkaline pretreated CS.

\section{MATERIALS AND METHODS}

\section{Material and microorganism}

All chemicals were purchased from Sigma (St. Louis, MO, USA) except those indicated. CS was obtained from Nu-3 (Queretaro, Mexico). Aspergillus niger GS1 (National Center for Biotechnology Information, NCBI No. GU395669) was provided by the Department of Food Research (UAQ, Queretaro, Mexico). A. niger GS1 was kept as spore suspension in $0.1 \%$ Tween 20 on silica gel (3:1 weight ratio) at $4^{\circ} \mathrm{C}$. Stock cultures were sub-cultured on fresh sterile potato dextrose agar (PDA; Bioxon, Cuautitlán, Mexico) plates and incubated for $72-120 \mathrm{hrs}$ at $30^{\circ} \mathrm{C}$ (Regalado et al. 2000).

Table 1. Factors and levels used for the $2^{9-5}$ fractional factorial design to improve xylanolytic activity production by Aspergillus niger GS1, using SSF with supplemented ACS.

\begin{tabular}{|c|c|c|}
\hline \multirow[t]{2}{*}{ Factor } & \multicolumn{2}{|c|}{ Level $\left(\mathrm{g} \mathrm{L}^{-1}\right)$} \\
\hline & Low (-1) & High (1) \\
\hline YE & 12 & 16 \\
\hline AS & 2.5 & 4.5 \\
\hline G & 6.0 & 9.0 \\
\hline SP & 3.0 & 4.0 \\
\hline MS & 0.30 & 0.70 \\
\hline IS & 0.10 & 0.30 \\
\hline PP & 2.0 & 4.0 \\
\hline ZS & 0.10 & 0.30 \\
\hline CUS & 0.008 & 0.016 \\
\hline
\end{tabular}

YE: yeast extract; AS: $\left(\mathrm{NH}_{4}\right)_{2} \mathrm{SO}_{4}$; G: glucose; SP: $\mathrm{Na}_{2} \mathrm{HPO}_{4}$; MS: $\mathrm{MgSO}_{4} \cdot 7 \mathrm{H}_{2} \mathrm{O}$; IS: $\mathrm{FeSO}_{4} \cdot 7 \mathrm{H}_{2} \mathrm{O}$; PP: $\mathrm{KH}_{2} \mathrm{PO}_{4} ; \mathrm{CUS} \mathrm{CuSO}_{4} \cdot 5 \mathrm{H}_{2} \mathrm{O}$; $\mathrm{ZS}: \mathrm{ZnSO}_{4}$.

\section{Cultures conditions}

SSF was carried out in glass column reactors $\left(15 \mathrm{~cm}\right.$ high, $2.5 \mathrm{~cm}$ in diameter), at $30^{\circ} \mathrm{C}$ with air flow of $60 \mathrm{~cm}^{3} \mathrm{~min}^{-1}$ in a water bath for up to $48 \mathrm{hrs}$. Solid substrate comprised CS reduced to a particule size of 0.0595-0.0841 mm (between US sieve series No. 20 and 30) using a Cemotec 1090 mill (Tecator, Hoganas, Sweden). Sieved CS was alkaline pre-treated using $4 \mathrm{~g} \mathrm{~L}^{-1} \mathrm{NaOH}$ in a weight ratio 1:10 (CS:alkaline solution) for $12 \mathrm{hrs}$ at room temperature and then excess $\mathrm{NaOH}$ was removed by rinsing with water until $\mathrm{pH}$ 7. Substrate moisture was adjusted to $800 \mathrm{~g} \mathrm{~kg}^{-1}$ by adding a solution of 
supplementary nutritional ingredients containing $\left(\mathrm{g} \mathrm{L}^{-1}\right)$ : yeast extract $(\mathrm{YE}), 10 ;\left(\mathrm{NH}_{4}\right)_{2} \mathrm{SO}_{4}(\mathrm{AS}), 1.5$; glucose (G), 6; $\mathrm{Na}_{2} \mathrm{HPO}_{4}(\mathrm{SP}), 3.4 ; \mathrm{MgSO}_{4} \cdot 7 \mathrm{H}_{2} \mathrm{O}$ (MS), 0.3; $\mathrm{FeSO}_{4} \cdot 7 \mathrm{H}_{2} \mathrm{O}$ (IS), $0.1 ; \mathrm{KH}_{2} \mathrm{PO}_{4}(\mathrm{PP}), 2.4$; $\mathrm{CuSO}_{4} \cdot 5 \mathrm{H}_{2} \mathrm{O}$ (CUS), $0.1 ; \mathrm{ZnSO}_{4}$ (ZS) 0.08 . Starting $\mathrm{pH}$ was adjusted to 6.5 and the substrate was

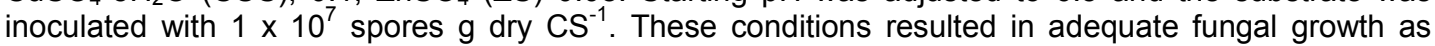
evaluated in previous experiments (Regalado et al. 2000, Lagunas-Bernabé et al. 2006).

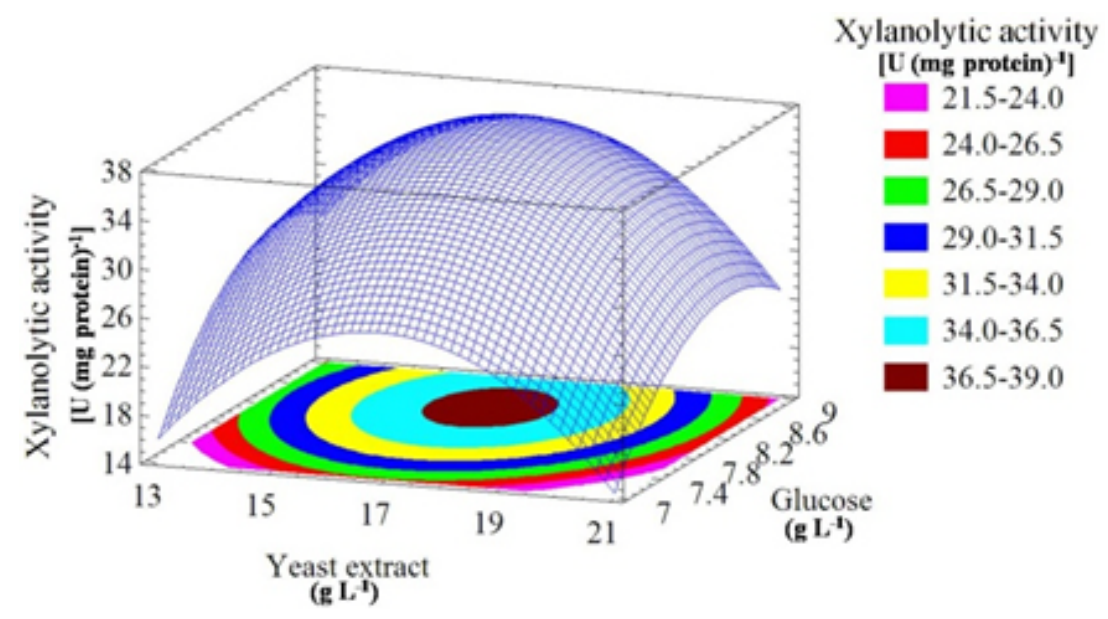

Fig. 1 Response surface plot of optimized xylanolytic activity production by A. niger GS1 using SSF with supplemented ACS as substrate.

\section{Semipurified enzyme extract}

Acetate buffer $(50 \mathrm{mM}, \mathrm{pH} 5.5)$ was added to the fermented product in a 1:1.5 volume ratio (buffer:product) and the crude extract was obtained by filtering through two layers of cheese cloth. The supernatant was filtered using a No. 2 Whatman paper followed by centrifugation at $15000 \times \mathrm{g}$ (Eppendorf, Mod. 5804R, Hamburg, Germany) for $10 \mathrm{~min}$ at $4^{\circ} \mathrm{C}$. Protein was precipitated by cold acetone $\left(-20^{\circ} \mathrm{C}\right)$ added in a $1: 3$ volume ratio (crude extract:acetone) and kept at $4^{\circ} \mathrm{C}$ for 2 hrs before centrifugation as described above. The precipitate was resuspended with acetate buffer, dialyzed, centrifuged, and the supernatant was filtered through $0.22 \mu \mathrm{m}$ membrane (Millipore, Billerica, MA, USA) and was labeled as semipurified enzyme extract (EE).

\section{Analytical methods}

CS sample was oven dried (WTC Binder, Tuttlingen, Germany) at $80^{\circ} \mathrm{C}$ until constant weight $(\sim 16 \mathrm{hrs})$. Ash, crude protein (Nx6.25) and ether extract were determined according to Association of Official Analytical Chemists (1995). Soluble protein content was determined according to Bradford (1976), using bovine serum albumin as standard.

Neutral detergent fiber (NDF) and acid detergent fiber (ADF) were evaluated using an ANKOM 200 digestion equipment (ANKOM Technology, Macedon, NY, USA) according to manufacturer instructions. Hemicellulose was determined by subtracting ADF from NDF. Samples subjected to ADF digestion were further treated with concentrated sulphuric acid $\left(720 \mathrm{~g} \mathrm{~kg}^{-1}\right)$ followed by drying and ashing, to estimate lignin (organic matter based). Subtraction of lignin from residue of ADF was used to determine cellulose content (ANKOM Technology, 2010). All determinations were done with and without alkaline pre-treatment, in triplicate.

\section{Xylanolytic enzymes assay}

Xylanolytic activity was determined using oats spelts xylan $\left(5 \mathrm{~g} \mathrm{~L}^{-1}\right)$, dissolved in $50 \mathrm{mM}$ acetate buffer, $\mathrm{pH}$ 5.5. Extracts were incubated with this solution at $50^{\circ} \mathrm{C}$ for $10 \mathrm{~min}$ followed by immersion in iced 
water. Reducing sugars released were quantified according to Sinner and Puls (1978) using a xylose standard curve. One activity unit (U) was defined as the amount of enzyme that releases $1 \mu \mathrm{mol}$ of xylose per min, at $50^{\circ} \mathrm{C}$.

\section{In vitro ruminal digestibility and true digestibility of dry matter}

In vitro ruminal digestibility of dry matter (RD) and in vitro true digestibility of dry matter (TD) were determined, where the latter comprises removal of microbial debris and any remaining soluble fractions. Each gram of dry alkaline pre-treated CS (ACS) was mixed with $1.6 \mathrm{U}$ of EE and moisture was adjusted to $800 \mathrm{~g} \mathrm{~kg}^{-1}$, followed by incubation of $0.25 \mathrm{~g}$ of this material during $0,4,8$, and $12 \mathrm{hrs}$. The reaction mixture was then treated with $2 \mathrm{~L}$ of cow's rumen taken from 18 months healthy Holstein bovine (INIFAP, Qro., Mexico). The above mentioned parameters were obtained as directed by (ANKOM Technology, 2010) during $48 \mathrm{hrs}$ and $72 \mathrm{hrs,} \mathrm{at} 39^{\circ} \mathrm{C}$ using a Daisy" incubator (ANKOM Technology).

\section{$\mathrm{CO}_{2}$ production}

Fungal growth was indirectly determined by $\mathrm{CO}_{2}$ released at conditions leading to optimal xylanolytic activity, measured by gas chromatography (Perkin-Elmer; Poraplot $Q$ column, $75^{\circ} \mathrm{C}$ injection temperature, thermal conductivity detector at $180^{\circ} \mathrm{C}$, He flow of $2 \mathrm{~mL} \mathrm{~min}^{-1}$ ).

\section{Experimental design}

The effect of nine supplementing nutrients (YE, AS, G, SP, MS, IS, PP, CUS, ZS) at two different levels on xylanase activity production from SSF of ACS, was tested using a $2^{9-5}$ fractional factorial design (Montgomery, 1991) (Table 1). The design comprised 16 treatments with two replicates (Table 2). The resulting four significant factors (Table 3 ) were employed to establish a Draper-Lin small central composite design with one replicate (Draper and Lin, 1990) to optimize xylanolytic activity, comprising 9 treatments (Table 4). All results were analyzed using statistical software (Statgraphics v. 5.0).

Table 2. Xylanolytic activity produced by $A$. niger GS1 using SSF with supplemented ACS, according to a $2^{9-5}$ fractional factorial design.

\begin{tabular}{|c|c|c|c|c|c|c|c|c|c|c|}
\hline $\mathrm{T}^{\mathrm{a}}$ & YE & AS & G & SP & MS & IS & PP & cus & ZS & $\begin{array}{c}\text { Xylanolytic } \\
\text { activity } \\
\left.[\mathrm{U} \text { (mg protein })^{-1}\right]^{b}\end{array}$ \\
\hline 1 & -1 & 1 & 1 & 1 & 1 & 1 & -1 & -1 & -1 & $7.4 \pm 2.0$ \\
\hline 2 & -1 & 1 & -1 & -1 & 1 & -1 & 1 & 1 & -1 & $N D^{c}$ \\
\hline 3 & 1 & 1 & -1 & 1 & -1 & 1 & 1 & -1 & -1 & $0.7 \pm 0.5$ \\
\hline 4 & 1 & -1 & -1 & 1 & -1 & -1 & 1 & 1 & 1 & $0.3 \pm 0.01$ \\
\hline 5 & -1 & -1 & 1 & 1 & 1 & -1 & -1 & 1 & 1 & $11 \pm 1.0$ \\
\hline 6 & 1 & -1 & 1 & -1 & -1 & 1 & -1 & -1 & 1 & $12 \pm 0.6$ \\
\hline 7 & -1 & -1 & -1 & 1 & -1 & -1 & -1 & -1 & -1 & $N D^{c}$ \\
\hline 8 & 1 & -1 & -1 & -1 & 1 & 1 & -1 & 1 & -1 & $1.2 \pm 0.5$ \\
\hline 9 & 1 & -1 & 1 & 1 & 1 & -1 & 1 & -1 & -1 & $11.7 \pm 0.1$ \\
\hline 10 & -1 & 1 & 1 & -1 & -1 & -1 & 1 & -1 & 1 & $6.5 \pm 1.0$ \\
\hline 11 & 1 & 1 & 1 & 1 & 1 & 1 & 1 & 1 & 1 & $6.5 \pm 0.5$ \\
\hline 12 & -1 & -1 & -1 & -1 & 1 & 1 & 1 & -1 & 1 & $N^{c}$ \\
\hline 13 & -1 & 1 & -1 & 1 & -1 & 1 & -1 & 1 & 1 & $1.3 \pm 0.03$ \\
\hline 14 & -1 & -1 & 1 & -1 & -1 & 1 & 1 & 1 & -1 & $6.0 \pm 0.6$ \\
\hline 15 & 1 & 1 & -1 & -1 & 1 & -1 & -1 & -1 & 1 & $2.0 \pm 0.7$ \\
\hline 16 & 1 & 1 & 1 & -1 & -1 & -1 & -1 & 1 & -1 & $4.0 \pm 1.4$ \\
\hline$P$-value & 0.008 & $<0.001$ & $<0.001$ & 0.060 & 0.023 & 0.924 & 0.068 & $<0.001$ & 0.011 & \\
\hline
\end{tabular}

${ }^{\mathrm{a}} \mathrm{T}=$ Treatment number. ${ }^{\mathrm{b}}$ Values are averages of data from three independent experiments \pm standard deviation. ${ }^{\mathrm{c}} \mathrm{ND}$ no detected. Factors symbols are shown in Table 1. 


\section{RESULTS AND DISCUSSION}

\section{Chemical analysis of CS}

Cellulose and hemicellulose were the major components of CS before and after alkaline pretreatment, while crude protein was relatively low (Table 5). The main effect of alkaline treatment was a reduction of $9 \%$ in NDF and $2 \%$ in ADF while a negligible effect occurred on ether extract, crude protein, and ash. A reduction in both hemicellulose $(20 \%)$ and lignin $(30 \%)$ was observed after alkaline pretreatment of CS, and was attributed to a partial hydrolysis of phenolic components (lignin) and/or ligninhemicellulose bonds (Sun and Cheng, 2002). Alkaline pre-treatment of agricultural by-products before fermentation has been reported to favour enzymatic hydrolysis (Chapla et al. 2010).

On the other hand, the type and content of CS hemicellulose may lead to induction mechanisms for specific A. niger xylanolytic genes (Dhiman et al. 2008). Depending on the carbon source and environmental conditions, the release of homo or hetero disaccharides by constitutively produced xylanases leads to the use of alternative metabolic pathways by $A$. niger. Concentration of mono- and di-saccharides may induce or repress xylanolytic enzymes transcription (Rizzatti et al. 2008). However, not all xylan sources act as xylanases inducers since their induction capacity is also dependent on the structure of the aglycon (Collins et al. 2005).

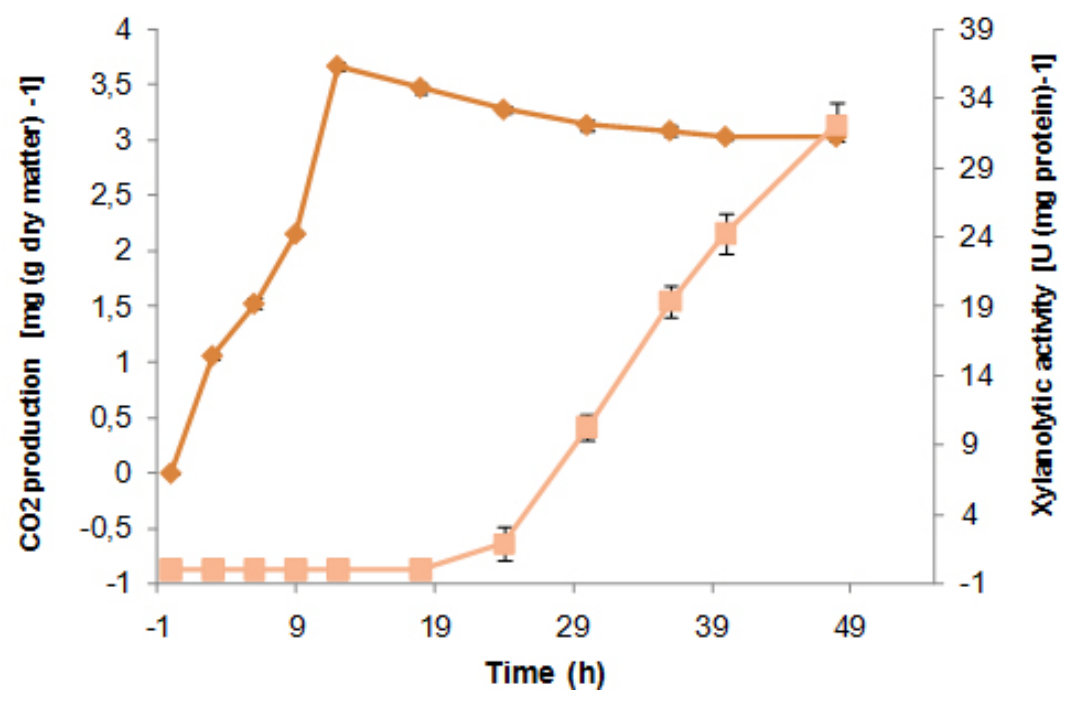

Fig. $2 \mathrm{CO}_{2}$ production $(\bullet)$ and xylanolytic activity $(\square)$ by $A$. niger GS1 during optimized SSF, with supplemented ACS as substrate.

\section{Effect of nutrient supplementation on optimization of xylanolytic enzymes production}

From the $2^{9-5}$ fractional factorial design, xylanolytic activity after 48 hrs of SSF ranged between not detected (ND) and $12 \pm 0.6 \cup(\mathrm{mg} \text { protein })^{-1}$ (Table 2$)$. These results agree with those reported by Rezende et al. (2002), and Okafor et al. (2007) where xylanase activity varied from 3.4 to $13 \mathrm{U}$ (mg protein $)^{-1}$. These authors used supplemented agricultural by-products such as sawdust, sugarcane pulp, wheat bran, and oat spelt xylan as substrates using either T. harzianum or A. niger ANL 301.

Statistical analysis indicated that YE, AS, G, and CUS exerted significant effect on xylanolytic activity using ACS as substrate $(P \leq 0.01)$ (Table 2). From prediction profile analyses of these four factors, ranges were established for each one (according to preliminary experiments) and arranged into a Draper-Lin design involving 18 treatments with one replicate (Table 4). Maximum xylanolytic activity was $29.2 \pm 2.8 \mathrm{U}$ (mg protein) ${ }^{-1}$ obtained from treatment 17 (Table 4). This activity is 2.4 times higher than the maximum achieved using fractional factorial design (treatment 6, Table 2), suggesting enhanced induction of xylanolytic activity by a decrease of about $9 \%$ in CUS concentration (Table 4). Despite $\mathrm{Cu}$ involvement as enzyme cofactor involved in pigmentation and catabolism of aromatic 
Table 3. Factors concentration at different levels of the Draper-Lin experimental design.

\begin{tabular}{|c|c|c|c|c|c|}
\hline \multirow[t]{2}{*}{ Factor } & \multicolumn{5}{|c|}{ Levels of Draper-Lin design $\left(\mathrm{g} \mathrm{L}^{-1}\right)$} \\
\hline & -1.68 & -1 & 0 & 1 & 1.68 \\
\hline YE & 12.5 & 13.5 & 15 & 16.5 & 17.5 \\
\hline AS & 1.24 & 1.75 & 2.5 & 3.25 & 3.76 \\
\hline G & 7.7 & 8.125 & 8.75 & 9.375 & 9.8 \\
\hline CUS & 0.0145 & 0.0156 & 0.017 & 0.0187 & 0.020 \\
\hline
\end{tabular}

Factors symbols are shown in Table 1.

compounds (Griffith et al. 2007), this result was expected because high $\mathrm{Cu}$ concentration may inhibit the electron transport chain interfering with basic fungal metabolic processes (Deacon, 1997). The model generated from the experimental results expressed in terms of real variables is shown in Equation 1. All terms included therein are significant $(P<0.055)$, with $\mathrm{R}^{2}=0.965$.

$Y=-278.3+20.39 \times Y E-21.19 \times A S+132.8 \times G-51110 \times C U S-0.8082 \times Y^{2}-1.906 \times Y E \times A S-$ $0.3067 \times Y E \times G+840.4 \times Y E \times C U S-8.196 \times A S^{2}+1.931 \times A S \times G+4389 \times A S \times C U S-9.230 \times G^{2}$ $+1997 \times$ x x CUS + $226100 \times$ CUS $^{2}$

[Equation 1]

From the statistical software, a stationary point was found giving a maximum predicted xylanolytic activity $(Y)$ of $33.6 \cup(\mathrm{mg} \text { protein })^{-1}$, together with optimum predicted levels for each factor tested. Predicted optimal supplementation of $\mathrm{YE}, \mathrm{AS}$, and $\mathrm{G}$, was $16.8,1.7,8.7 \mathrm{~g} \mathrm{~L}^{-1}$, respectively. On the other hand, predicted optimum CUS concentration of $14.5 \mathrm{mg} \mathrm{L}^{-1}$ remained the same as treatment 17 (Table 4). Different concentrations of $G$ and $Y E$, at the optimal predicted values of AS and CUS were used to construct a three dimensional response surface plot where maximum xylanolytic activity is shown (Figure 1). Three confirmatory experiments using the optimized factors concentration gave 32.8 $\pm 1.6 \cup(\mathrm{mg} \text { protein })^{-1}$, in agreement with the predicted value. An optimized xylanolytic activity of $49.3 \pm$ $2 U(\mathrm{mg} \text { protein })^{-1}$ was achieved by SSF of wheat bran using $A$. versicolor MKU3 after 72 hrs of incubation (Jeya et al. 2005). However, higher activity was reported when two mutant $A$. niger strains (N218 and P602) were subjected to SSF for $72 \mathrm{hrs}$ and $48 \mathrm{hrs}$ yielding about 330 and $665 \mathrm{U}$ (mg protein $)^{-1}$, respectively. Substrate used was a mixture of supplemented corn cob, wheat bran and wheat straw in a 0.533:0.333:0.133 weight ratio (Wu et al. 2005). Despite these promising results mutation mechanism and stability of mutants were not reported, and thus confirmation of uniform activity production with time needs further evaluation.

\section{$\mathrm{CO}_{2}$ production and enzymatic activity during SSF}

As a result of fungal metabolic activity $\mathrm{CO}_{2}$ production was measured to indirectly evaluate $A$. niger GS1 growth during SSF. Released $\mathrm{CO}_{2}$ steadily increased up to a maximum value after 12 hrs of SSF (Figure 2). This behaviour was attributed to the use of the readily available carbon source (glucose) added to nutrients supplementation. From about $12 \mathrm{hrs}$ of SSF a slight decrease in total $\mathrm{CO}_{2}$ production was observed, probably associated to the exhaustion of glucose and the beginning of hydrolysis of CS cellulose and hemicelluloses. This might have been achieved by induced xylanolytic among other fibrolytic enzymes. Despite a slight decrease in total $\mathrm{CO}_{2}$ released this process continued until $48 \mathrm{hrs}$ of SSF, where spore formation was noticed. Preliminary experiments with SSF of corn cob showed that $A$. niger GS1 produced a maximal total $\mathrm{CO}_{2}$ after $24 \mathrm{hrs}$ of incubation. An extended adaptation time of $10 \mathrm{hrs}$ was observed since glucose was not added, leading to a slower fungal growth with a maximum xylanolytic activity production of $27.5 \mathrm{U}$ (mg protein) $)^{-1}$ after $48 \mathrm{hrs}$ of SSF (results not shown). Even though we used a different substrate, lag time was highly decreased in our experiments by supplementing small amounts of glucose achieving $20 \%$ higher xylanolytic activity. These results suggest that xylanolytic activity varies according to the type of substrate, indicating that optimization is a crucial step for each fermentation system. 

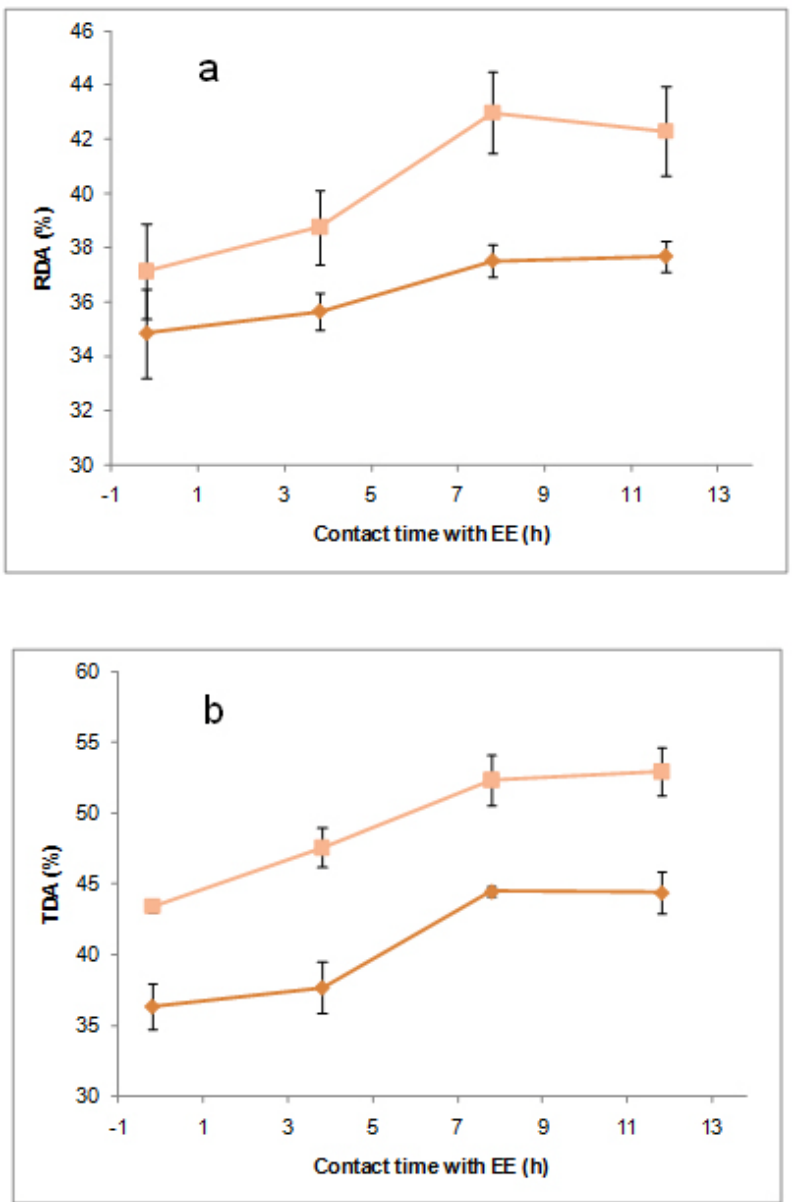

Fig. 3 Digestibility of ACS exposed to semipurified enzymatic extract (EE) [1.6 U xylanase activity (g dry

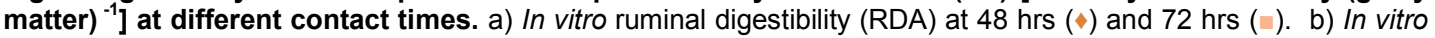

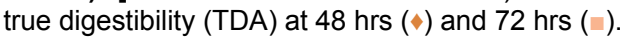

Additionally, Graminha et al. (2008) reported that solid residues from SSF after fungal growth can be used as protein, total lipid and fatty acids-enriched feed additives with high degradability and low antinutritional factors for ruminants.

\section{Effect of semipurified enzyme extract on CS}

No significant difference on hemicellulose content was noted by adding enzyme crude extract to CS without alkaline pre-treatment (data not shown). However, after a contact time of 8 hrs and 12 hrs between $A C S$ and XE, significantly lower NDF, ADF, hemicellulose, cellulose and lignin values were observed $(P<0.01)$ corresponding to a decrease of $4.3,2.1,11.9,9.6$ and $14.6 \%$, respectively (Table $6)$. These results confirm that $A$. niger cell wall hydrolytic enzymes require a pre-degradation, provided by alkaline pre-treatment to gain access to its substrate.

\section{In vitro ruminal digestibility and true digestibility of CS}

No significant difference was found over in vitro ruminal digestibility of CS dry matter (RD) before alkaline pre-treatment, with or without contacting with EE even up to $12 \mathrm{hrs}$, followed by 48 hrs or 72 hrs of ruminal digestion (data not shown). Similar behaviour was observed for in vitro true digestibility of CS dry matter (TD) without alkaline pre-treatment, even for up to $12 \mathrm{hrs}$ exposure to EE, and up to $72 \mathrm{hrs}$ of ruminal digestion (data not shown). 
Table 4. Draper-Lin design to optimize xylanolytic activity from SSF of supplemented ACS using four factors, with two central points.

\begin{tabular}{|c|c|c|c|c|c|}
\hline$T^{a}$ & YE & AS & G & cus & $\begin{array}{l}\text { Xylanolytic activity } \\
\left.[\mathrm{U} \text { (mg protein })^{-1}\right]^{\mathrm{b}}\end{array}$ \\
\hline 1 & -1 & 1 & 1 & 1 & $16.38 \pm 1.41$ \\
\hline 2 & -1 & -1 & 1 & -1 & $15.32 \pm 2.12$ \\
\hline 3 & -1 & 1 & -1 & 1 & $3.44 \pm 1.84$ \\
\hline 4 & 0 & 1.68 & 0 & 0 & $10.41 \pm 1.83$ \\
\hline 5 & 0 & 0 & 1.68 & 0 & $18.11 \pm 2.82$ \\
\hline 6 & -1 & -1 & -1 & -1 & $13.74 \pm 0.99$ \\
\hline 7 & -1.68 & 0 & 0 & 0 & $8.67 \pm 1.17$ \\
\hline 8 & 1 & 1 & 1 & -1 & $13.9 \pm 4.24$ \\
\hline 9 & 1 & -1 & -1 & 1 & $6.74 \pm 0.99$ \\
\hline 10 & 0 & 0 & 0 & 0 & $21.17 \pm 0.04$ \\
\hline 11 & 0 & 0 & 0 & 0 & $21.17 \pm 0.57$ \\
\hline 12 & 1.68 & 0 & 0 & 0 & $24.37 \pm 0.85$ \\
\hline 13 & 0 & 0 & 0 & 1.68 & $17.21 \pm 0.70$ \\
\hline 14 & 0 & 0 & -1.68 & 0 & $4.82 \pm 0.85$ \\
\hline 15 & 1 & -1 & 1 & 1 & $14.91 \pm 2.06$ \\
\hline 16 & 0 & -1.68 & 0 & 0 & $6.84 \pm 1.41$ \\
\hline 17 & 0 & 0 & 0 & -1.68 & $29.19 \pm 2.83$ \\
\hline 18 & 1 & 1 & -1 & -1 & $9.85 \pm 0.99$ \\
\hline
\end{tabular}

${ }^{\mathrm{a}} \mathrm{T}=$ treatment. ${ }^{\mathrm{b}}$ Values represent mean of two independent experiments \pm standard deviation. Factors symbols are shown in Table 1.

However, a $2.5 \%$ and $5.3 \%$ increase over in vitro ruminal digestibility of ACS (RDA) was obtained by contacting with EE for up to $12 \mathrm{hrs}$, before $48 \mathrm{hrs}$ and $72 \mathrm{hrs}$ ruminal digestion, respectively (Figure 3a). Additionally, an increment of $9 \%$ and $10 \%$ over in vitro true digestibility of ACS (TDA) was observed after $48 \mathrm{hrs}$ and $72 \mathrm{hrs}$ ruminal digestion, with previous exposure to EE for 12 hrs (Figure $3 b)$. Similar results were reported for alfalfa hay fed to sheep where a $6.3 \%$ increase on dry matter digestibility and $11.7 \%$ more hemicellulose digestibility (Pinos-Rodríguez et al. 2002). However, addition of commercial fibrolytic enzymes, mainly endoglucanase and xylanase directly fed into sheep's rumen at a rate of 0 or $12 \mathrm{~g} \mathrm{~d}^{-1}$, did not correlate with in situ dry matter and NDF degradation of grass hay (Giraldo et al. 2008). A synergistic action between rumen and exogenous fibrolytic enzymes being active at physiological digestive conditions has been reported (Morgavi et al. 2000). Therefore, further experiments are needed to test our EE as a ruminant feed additive to enhance meat or milk productivity.

Table 5. Chemical composition of CS with and without alkaline pre-treatment with $40 \mathrm{~g} \mathrm{~L}^{-1} \mathrm{NaOH}$.

\begin{tabular}{ccc}
\hline $\begin{array}{c}\text { Chemical composition } \\
\text { (weight \%) }\end{array}$ & $\begin{array}{c}\text { Without alkaline } \\
\text { pre-treatmen }^{\mathbf{t}}\end{array}$ & $\begin{array}{c}\text { With alkaline } \\
\text { pre-treatmen }^{\mathbf{t}}\end{array}$ \\
Totals solids & $95.0 \pm 0.1$ & $95.0 \pm 0.1$ \\
Protein & $5.0 \pm 0.1$ & $5.4 \pm 0.1$ \\
Ether extract & $1.48 \pm 0.1$ & $1.40 \pm 0.1$ \\
Ash & $5.5 \pm 0.1$ & $5.8 \pm 0.1$ \\
NDF & $77.0 \pm 0.1$ & $70.6 \pm 0.1$ \\
ADF & $46.5 \pm 0.1$ & $45.8 \pm 0.1$ \\
Hemicellulose & $30.4 \pm 0.1$ & $24.2 \pm 0.1$ \\
Cellulose & $38.0 \pm 0.1$ & $37.2 \pm 0.1$ \\
Lignin & $7.85 \pm 0.03$ & $5.56 \pm 0.04$ \\
\hline
\end{tabular}

${ }^{a}$ Values represent mean of three independent experiments \pm standard deviation. Significant difference was only found for hemicellulose and lignin contents $(P<0.05)$. 
On the other hand, release of xylooligosaccharides mediated by xylanolytic enzymes into the rumen compartment can positively balance gastrointestinal microbiota, and thereby improve animal production and health. Furthermore, this benefit could stabilize ruminal $\mathrm{pH}$ and decrease the risk of acidosis which is not only responsible for a decrease in animal performance, but is also often related to health issues such as laminitis, bloat, or liver abscess (Enemark, 2008).

We conclude that employing statistical design of experiments and RSM an optimized xylanolytic activity of 33.6 U (mg protein) $)^{-1}$ was produced, using supplemented ACS as substrate upon SSF with native $A$. niger GS1, during 48 hrs. EE may improve utilization of agroindustrial by-products such as ACS into ruminant feed for meat or milk productivity and animal health. Despite the observed promising results, the use of alkaline pre-treatment may cause environmental concern. Further research to design an alternative eco-friendly pre-treatment capable to expose substrate to hydrolytic enzymes needs to be done.

Table 6. Chemical composition of alkaline pre-treated $\left(40 \mathrm{~g} \mathrm{~L}^{-1} \mathrm{NaOH}\right) \mathrm{CS}(1: 10 \mathrm{v} / \mathrm{v}$ ratio, CS:alkali solution) at different EE [1.6 $\mathrm{U}$ xylanase activity $\left.\left(\mathrm{g}_{\text {dry }} \mathrm{ACS}\right)^{-1}\right]$ contact times (ACS moisture content $=800 \mathrm{~g} \mathrm{~kg}^{-1}$ ).

\begin{tabular}{cccccc}
\hline Contact time (hrs) & $\begin{array}{c}\text { NDF } \\
\text { (weight \%) }^{\mathrm{c}}\end{array}$ & $\begin{array}{c}\text { ADF } \\
\text { (weight \%) }^{\mathrm{d}}\end{array}$ & $\begin{array}{c}\mathbf{H} \\
\text { (weight \%) }^{\mathrm{e}}\end{array}$ & $\begin{array}{c}\mathbf{C} \\
\text { (weight \%) }^{\mathrm{f}}\end{array}$ & $\begin{array}{c}\text { L } \\
\text { (weight \%) }^{\mathrm{g}}\end{array}$ \\
\hline 0 & $70 \pm 0.5^{\mathrm{a}}$ & $47 \pm 0.3^{\mathrm{a}}$ & $21.8 \pm 0.5^{\mathrm{a}}$ & $36.5 \pm 0.5^{\mathrm{a}}$ & $5.5 \pm 0.04^{\mathrm{a}}$ \\
4 & $69 \pm 0.6^{\mathrm{a}}$ & $47 \pm 0.2^{\mathrm{a}}$ & $21.6 \pm 0.8^{\mathrm{a}}$ & $35.4 \pm 0.5^{\mathrm{a}}$ & $5.5 \pm 0.04^{\mathrm{a}}$ \\
12 & $67 \pm 0.5^{\mathrm{b}}$ & $46 \pm 0.2^{\mathrm{a}}$ & $19.2 \pm 0.1^{\mathrm{b}}$ & $33 \pm 0.2^{\mathrm{b}}$ & $4.7 \pm 0.05^{\mathrm{b}}$ \\
\hline
\end{tabular}

${ }^{\mathrm{C}} \mathrm{NDF}=$ Neutral detergent fiber. ${ }^{\mathrm{d}} \mathrm{ADF}=$ Acid detergent fiber. ${ }^{\mathrm{e}} \mathrm{H}=$ Hemicellulose. ${ }^{\mathrm{f}} \mathrm{C}=$ Cellulose. ${ }^{\mathrm{g}} \mathrm{L}=\mathrm{Lignin}$. Values represent mean of three independent experiments \pm standard deviation. Different letters in same column indicate significant differences at $P<0.05$.

Financial support: Consejo Nacional de Ciencia y Tecnología (México) for MS fellowship to I.V.O. and Ph D fellowship to A.A.R.

\section{REFERENCES}

AGRIFOOD AND FISHERY INFORMATION SERVICE. (2010). Avance de siembras y cosechas. Año agricola 2010, Riego+Temporal al 31 de enero de 2010. [Online] México, D.F., SIAP. [cited 3 March 2010]. Available from Internet: http://www.siap.gob.mx/.

ANKOM TECHNOLOGY. (2010). Procedures. [Online] Macedon, NY, ANKOM Technology. [cited 20 September 2010]. Available from Internet: http://www.ankom.com/procedures.aspx.

ASSOCIATION OF OFFICIAL ANALYTICAL CHEMISTS. (1995). Official methods of analysis of the Association of Official Analytical Chemists, $16^{\text {th }}$ ed. AOAC, Gaithersburg, MD.

BEG, Q.K.; KAPOOR, M.; MAHAJAN, L. and HOONDAL, G. (2001). Microbial xylanases and their industrial applications: A review. Applied Microbiology and Biotechnology, vol. 56, no. 3-4, p. 326-338. [CrossRef]

BETINI, J.H.A.; MICHELIN, M.; PEIXOTO-NOGUEIRA, S.C.; JORGE, J.A.; TERENZI, H.F. and POLIZELI, M.L.T.M. (2009). Xylanases from Aspergillus niger, Aspergillus niveus and Aspergillus ochraceus produced under solid-state fermentation and their application in cellulose pulp bleaching. Bioprocess and Biosystems Engineering, vol. 32, no. 6, p. 819-824. [CrossRef]

BRADFORD, M.M. (1976). A rapid and sensitive method for the quantitation of microgram quantities of protein utilizing the principle of protein-dye binding. Analytical Biochemistry, vol. 72, no. 1-2, p. 248-254.

CHAPLA, D.; DIVECHA, J.; MADAMWAR, D. and SHAH, A. (2010). Utilization of agro-industrial waste for xylanase production by Aspergillus foetidus MTCC 4898 under solid state fermentation and its application in saccharification. Biochemical Engineering Journal, vol. 49, no. 3, p. 361-369. [CrossRef]

COLLINS, T.; GERDAY, C. and FELLER, G. (2005). Xylanases, xylanase families and extremophilic xylanases. FEMS Microbiology Reviews, vol. 29, no. 1, p. 3-23. [CrossRef]

DEACON, J. (1997). Modern Mycology, Blackwell Science, London. 303 p. ISBN 0-632-03077-1.

DHIMAN, S.S.; SHARMA, J. and BATTANA, B. (2008). Industrial applications and future prospects of microbial xylanases: A review. BioResources, vol. 3, no. 4, p. 1377-1402.

DRAPER, N.R. and LIN, D.K.J. (1990). Small response surface designs. Technometrics, vol. 32, no. 2, p. 187-194.

ENEMARK, J.M.D. (2008). The monitoring, prevention and treatment of sub-acute ruminal acidosis (SARA): A review. The Veterinary Journal, vol. 176, no. 1, p. 32-43. [CrossRef]

EUN, J.S.; BEAUCHEMIN, K.A. and SCHULZE, H. (2007). Use of exogenous fibrolytic enzymes to enhance in vitro fermentation of alfalfa hay and corn silage. Journal of Dairy Science, vol. 90, no. 3, p. 1440-1451. [CrossRef] 
GIGER-REVERDIN, S. (2000). Characterisation of feedstuffs for ruminants using some physical parameters. Animal Feed Science and Technology, vol. 86, no. 1-2, p. 53-69. [CrossRef]

GIRALDO, L.A.; TEJIDO, M.L.; RANILLA, M.J.; RAMOS, S. and CARRO, M.D. (2008). Influence of direct-fed fibrolytic enzymes on diet digestibility and ruminal activity in sheep fed a grass hay-based diet. Journal of Animal Science, vol. 86, no. 7, p. 1617-1623. [CrossRef]

GRAMINHA, E.B.N.; GONÇALVES, A.Z.L.; PIROTA, R.D.P.B.; BALSALOBRE, M.A.A.; DA SILVA, R. and GOMES, E. (2008). Enzyme production by solid-state fermentation: Application to animal nutrition. Animal Feed Science and Technology, vol. 144, no. 1-2, p. 1-22. [CrossRef]

GRIFFITH, G.H., EASTON, G.L.; DETHERIDGE, A.; RODERICK, K.; EDWARDS, A.; WORGAN, H.J.; NICHOLSON, J. and PERKINS, W.T. (2007). Copper deficiency in potato dextrose agar causes reduced pigmentation in cultures of various fungi. FEMS Microbiology Letters, vol. 276, no. 2, p. 165-171. [CrossRef]

JEYA, M.; THIAGARAJAN, S. and GUNASEKARAN, P. (2005). Improvement of xylanase production in solid-state fermentation by alkali tolerant Aspergillus versicolor MKU3. Letters in Applied Microbiology, vol. 41, no. 2, p. 175-178. [CrossRef]

KAVYA, V. and PADMAVATHI, T. (2009). Optimization of growth conditions for xylanase production by Aspergillus niger in solid state fermentation. Polish Journal of Microbiology, vol. 58, no. 2, p. 125-130.

KRISHNA, C. (2005). Solid-state fermentation systems-an overview. Critical Reviews in Biotechnology, vol. 25, no. 1-2, p. 1-30. [CrossRef]

LAGUNAS-BERNABÉ, I.; GARCÍA-ALMENDÁREZ, B.; CASTAÑO-TOSTADO, E.; REGALADO-GONZÁLEZ, C. and ÁVILA-GONZÁLEZ, E. (2006). Production of hemicellulolytic enzymes through solid substrate fermentation and their application in the production of balanced feed for broilers. Veterinaria México, vol. 37, no. 1, p. 1-12.

LIU, C.; SUN, Z.; DU, J. and WANG, J. (2008). Response surface optimization of fermentation conditions for producing xylanase by Aspergillus niger SL-05. Journal of Industrial Microbiology and Biotechnology, vol. 35 , no. 7, p. 703-711. [CrossRef]

MAALEJ-ACHOURI, I.; GUERFALI, M.; GARGOURI, A. and BELGHITH, H. (2009). Production of xylooligosaccharides from agro-industrial residues using immobilized Talaromyces thermophilus xylanase. Journal of Molecular Catalysis B: Enzymatic, vol. 59, no. 1-3, p. 145-152. [CrossRef]

MONTGOMERY, D.C. (1991). Design and Analysis of Experiments. $5^{\text {th }}$ ed. John Wiley and Sons, New York, NY. 680 p. ISBN 047152994X.

MORGAVI, D.P.; BEAUCHEMIN, K.A.; NSEREKO, V.L.; RODE, L.M.; IWAASA, A.D.; YANG, W.Z.; MCALLISTER, T.A. and WANG, Y. (2000). Synergy between ruminal fibrolytic enzymes and enzymes from Trichoderma longibrachiatum. Journal of Dairy Science, vol. 83, no. 6, p. 1310-1321. [CrossRef]

OKAFOR, U.; OKOCHI, V.; ONYEGEME-OKERENTA, B. and NWODO-CHINEDU, S. (2007). Xylanase production by Aspergillus niger ANL 301 using agro-wastes. African Journal of Biotechnology, vol. 6, no. 14, p. 17101714.

PANDEY, A. (2003). Solid-state fermentation. Biochemical Engineering Journal, vol. 13, no. 2-3, p. 81-84. [CrossRef]

PINOS-RODRÍGUEZ, J.M.; GONZÁLEZ, S.S.; MENDOZA, G.D.; BÁRCENA, R.; COBOS, M.A.; HERNÁNDEZ, A. and ORTEGA, M.E. (2002). Effect of exogenous fibrolytic enzyme on ruminal fermentation and digestibility of alfalfa and rye-grass hay fed to lambs. Journal of Animal Science, vol. 80, no. 11, p. 3016-3020.

REGALADO, C.; GARCÍA-ALMENDÁREZ, B.; VENEGAS-BARRERA, L.; TELLEZ-JURADO, A.; RODRÍGUEZSERRANO, G.; HUERTA-OCHOA, S. and WHITAKER, J. (2000). Production, partial purification and properties of $\beta$-mannanases obtained by solid substrate fermentation of spent soluble coffee wastes and copra paste using Aspergillus oryzae and Aspergillus niger. Journal of the Science of Food and Agriculture, vol. 80, no. 9, p. 1343-1350.

REZENDE, M.I.; BARBOSA, A.; VASCONCELOS, A.F.D. and ENDO, A.S. (2002). Xylanase production by Trichoderma harzianum rifai by solid state fermentation on sugarcane bagasse. Brazilian Journal of Microbiology, vol. 33, no. 1, p. 67-72. [CrossRef]

RIZZATTI, A.C.S.; FREITAS, F.Z.; BERTOLINI, M.C.; PEIXOTO-NOGUEIRA, S.C.; TERENZI, H.F.; JORGE, J.A. and POLIZELI, M.L.T.M. (2008). Regulation of xylanase in Aspergillus phoenicis: A physiological and molecular approach. Journal of Industrial Microbiology and Biotechnology, vol. 35, no. 4, p. 237-244. [CrossRef]

SINNER, M. and PULS, J. (1978). Non-corrosive dye reagent for detection of reducing sugars in borate complex ion-exchange chromatography. Journal of Chromatography A, vol. 156, no. 1, p. 197-204. [CrossRef]

SUN, Y. and CHENG, J. (2002). Hydrolysis of lignocellulosic materials for ethanol production: A review. Bioresource Technology, vol. 83, no. 1, p. 1-11. [CrossRef]

WU, M.; LI, S.; YAO, J.; PAN, R. and YU, Z. (2005). Mutant of a xylanase-producing strain of Aspergillus niger in solid state fermentation by low energy ion implantation. World Journal of Microbiology and Biotechnology, vol. 21, no. 6-7, p. 1045-1049. [CrossRef] 
How to cite this article:

REGALADO, C.; VÁZQUEZ-OBREGÓN, I.; GARCÍA-ALMENDÁREZ, B.E.; DOMÍNGUEZDOMÍNGUEZ, J.; AGUILERA-BARREYRO, A. and AMARO-REYES, A. (2011). Xylanolytic enzymes production by Aspergillus niger GS1 from solid-state fermentation on corn stover and their effect on ruminal digestibility. Electronic Journal of Biotechnology, vol. 14, no. 2. http://dx.doi.org/10.2225/vol14-issue2-fulltext-3 